\title{
Influence of dissolved oxygen on the nitrification kinetics in a circulating bed biofilm reactor
}

\author{
R. Nogueira, V. Lazarova, J. Manem, L.F. Melo
}

\begin{abstract}
The influence of dissolved oxygen concentration on the nitrification kinetics was studied in the circulating bed reactor (CBR). The study was partly performed at laboratory scale with synthetic water, and partly at pilot scale with secondary effluent as feed water. The nitrification kinetics of the laboratory CBR as a function of the oxygen concentration can be described according to the half order and zero order rate equations of the diffusionreaction model applied to porous catalysts. When oxygen was the rate limiting substrate, the nitrification rate was close to a half order function of the oxygen concentration. The average oxygen diffusion coefficient estimated by fitting the diffusion-reaction model to the experimental results was around $66 \%$ of the respective value in water. The experimental results showed that either the ammonia or the oxygen concentration could be limiting for the nitrification kinetics. The latter occurred for an oxygen to ammonia concentration ratio below 1.5-2 $\mathrm{gO}_{2} / \mathrm{gN}^{-\mathrm{NH}_{4}^{+}}$ for both laboratory and pilot scale reactors. The volumetric oxygen mass transfer coefficient $\left(k_{L} a\right)$ determined in the laboratory scale reactor was $0.017 \mathrm{~s}^{-1}$ for a superficial air velocity of $0.02 \mathrm{~m} \mathrm{~s}^{-1}$, and the one determined in the pilot scale reactor was $0.040 \mathrm{~s}^{-1}$ for a superficial air velocity of $0.031 \mathrm{~m} \mathrm{~s}^{-1}$. The $k_{L} a$ for the pilot scale reactor did not change significantly after biofilm development, compared to the value measured without biofilm.
\end{abstract}

\begin{tabular}{ll}
$\begin{array}{l}\text { List of } \\
a\end{array}$ & \multicolumn{2}{c}{$\mathrm{m}^{2} \mathrm{~m}^{-3}$} \\
$C_{L, \mathrm{O}_{2}}$ & $\mathrm{mgO}_{2} 1^{-1}$ \\
$C_{L, \mathrm{O}_{2}}^{*}$ & $\mathrm{mgO}_{2} \mathrm{I}^{-1}$
\end{tabular}

specific mass transfer surface area of the gas bubbles actual dissolved oxygen concentration dissolved oxygen concentration at saturation conditions

Received: 5 January 1998

R. Nogueira, L.F. Melo

University of Minho, Dept. Bioengineering, 4700 Braga, Portugal

V. Lazarova, J. Manem

Centre of International Research for Water and Environment (CIRSEE), Lyonnaise des Eaux, 38 rue du président Wilson, 78230 Le Pecq, France

Correspondence to: L.F. Melo

Financial support of program PRAXIS XXI through Project 2/2.1/ Bio/37/94 program INTERREG and Lyonnaise des Eaux is gratefully acknowledged.

\begin{tabular}{|c|c|}
\hline$D_{\mathrm{fO}_{2}}$ & $\mathrm{~m}^{2} \mathrm{~s}^{-1}$ \\
\hline $\begin{array}{l}D M \\
D O\end{array}$ & $\begin{array}{l}\mathrm{kgDM} \mathrm{m} \\
\mathrm{mgO}_{2} 1^{-1}\end{array}$ \\
\hline$D_{\mathrm{W}, \mathrm{O}_{2}}$ & $\mathrm{~m}^{2} \mathrm{~s}^{-1}$ \\
\hline $\begin{array}{l}L_{\mathrm{f}} \\
k_{1 / 2 \mathrm{aO}_{2}}\end{array}$ & $\mathrm{gO}_{2}^{0.5} \mathrm{~m}^{-0.5} \mathrm{~d}^{-1}$ \\
\hline$k_{0 \mathrm{a}_{\mathrm{N}}}$ & $\mathrm{gN}-\mathrm{NH}_{4}^{+} \mathrm{m}^{-2} \mathrm{~d}^{-1}$ \\
\hline$k_{0 \mathrm{f}_{\mathrm{N}}}$ & $\mathrm{gN}-\mathrm{NH}_{4}^{+} \mathrm{m}^{-3} \mathrm{~d}^{-1}$ \\
\hline$k_{L} a$ & $s^{-1}$ \\
\hline$r_{a_{\mathrm{N}}}$ & $\mathrm{gN}-\mathrm{NH}_{4}^{+} \mathrm{m}^{-2} \mathrm{~d}^{-1}$ \\
\hline$r_{\mathrm{N}-\mathrm{NO}_{2}^{-}}$ & $\mathrm{kgN}-\mathrm{NO}_{2}^{-} \mathrm{m}^{-3} \mathrm{~d}^{-1}$ \\
\hline$r_{\mathrm{N}-\mathrm{NO}_{3}^{-}}$ & $\mathrm{kgN}-\mathrm{NO}_{3}^{-} \mathrm{m}^{-3} \mathrm{~d}^{-1}$ \\
\hline $\begin{array}{l}r_{\mathrm{O}_{2}} \\
T P\end{array}$ & $\begin{array}{l}\mathrm{kgO}_{2} \mathrm{~m}^{-3} \mathrm{~d}^{-1} \\
\mathrm{kgPT} \mathrm{m}^{-3} \text { reactor }\end{array}$ \\
\hline$U_{\mathrm{g}}$ & $\mathrm{m} \mathrm{s}^{-1}$ \\
\hline$v_{\mathrm{O}_{2} / \mathrm{N}}^{8}$ & $\mathrm{gO}_{2} / \mathrm{gN}-\mathrm{NH}_{4}^{+}$ \\
\hline
\end{tabular}

oxygen diffusion coefficient in the biofilm dry matter concentration dissolved oxygen concentration molecular oxygen diffusion in water biofilm thickness apparent half order oxygen rate constant apparent zero order ammonia rate constant intrinsic ammonia rate constant volumetric oxygen mass transfer coefficient nitrification rate nitrite conversion rate nitrate conversion rate oxygen conversion rate total protein concentration superficial air velocity stoichiometric constant for ammonia oxidation (taken as 4.57)

1

\section{Introduction}

Nitrogen compounds like ammonia and nitrate can be found in many wastewaters and need to be removed in order to prevent oxygen depletion and eutrophication of surface waters. Often, ammonia biological removal from wastewater is problematic because of the low growth rate and growth yield of the bacteria involved. Due to the increasing volumes of wastewater combined with limited space availability and progressively tightening international standards, new intensive biotechnologies for wastewater treatment are being developed.

Immobilisation of biomass in the form of biofilms is an efficient method to retain slow growing microorganisms in continuous flow reactors. Fixed biomass processes offer several advantages compared with conventional biological treatments: higher volumetric load, increased process stability and compactness of the reactors. However, thick biofilm development poses a problem with respect to oxygen transport to the microorganisms. Generally the average oxygen penetration depth in biofilms is around 100 to $200 \mu \mathrm{m}$ [1]. For this reason the biofilm thickness should be preferably in the same range and a high biofilm surface 
area is required in order to obtain maximal volumetric conversion rates.

It is generally agreed that, at least as a first approximation, the biofilm diffusion-reaction process can be modeled in a manner which is analogous to the description of a chemical reaction taking place in a porous catalyst [2-6]. According to this basic theory, biofilm reactor performance depends on the diffusional resistance of the biofilm to the penetration of substrates (ammonia and oxygen for nitrification processes). If the biofilm is fully penetrated by both substrates, then the overall process is reaction rate limited and the nitrification kinetics is described by a zero order equation. Otherwise, the diffusional resistance to the penetration of either the substrates is controlling the overall reaction and the nitrification kinetics is a half order function of the substrate concentration which penetrates the biofilm the least.

In biofilm systems the maximum volumetric conversion rate is usually limited by the liquid-biofilm [7] or the gasliquid oxygen mass transfer rate [8]. This study is aimed at investigating the influence of dissolved oxygen in the kinetics of ammonia removal in a circulating bed reactor at laboratory and pilot scales.

\section{2}

\section{Experimental}

\section{1}

\section{Experimental set-up}

The circulating bed reactor (CBR), as shown in Fig. 1, is a three phase-bioreactor. It has a rectangular geometry and is divided into two sections: an up flow aerated section (riser) and a down flow non aerated section (downcomer). The support for the biomass $(24 \% \mathrm{v} / \mathrm{v})$ is an irregular plastic granular product with a diameter between 0.5 and $3 \mathrm{~mm}$ and an average density of $0.87 \mathrm{~g} \mathrm{~cm}^{-3}$. A homogeneous three phase circulation (liquid-gas-solid) is induced by the injection of air in the riser. The geometry and op-

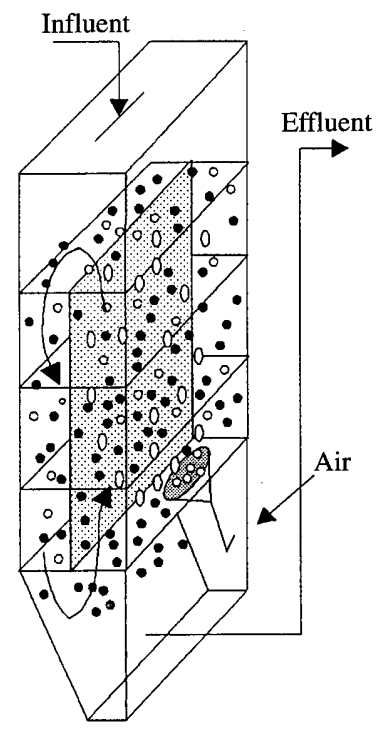

Fig. 1. The Circulating Bed Reactor (CBR) configuration erating conditions of the laboratory and pilot scale reactors used in the present work are summarised in Table 1.

\section{Laboratory scale reactor operation}

A series of preliminary batch experiments were carried out to promote microbial adhesion and initial biofilm formation. The support medium was seeded in a batch fermenter with a nitrifying bacterial suspension using an enrichment medium [9]. The bacterial suspension was obtained from the sedimentation tank downstream of a nitrifying biofilm reactor. Afterwards, the support medium was introduced in the circulating bed reactor which was continuously fed with a solution of $50 \mathrm{mgN}-\mathrm{NH}_{4}^{+} \mathrm{l}^{-1}$ in a synthetic medium composed of tap water, ammonium sulfate, sodium hydrogenocarbonate and potassium dihydrogenophosphate. The ratios $\mathrm{HCO}_{3}^{-} / \mathrm{N}-\mathrm{NH}_{4}^{-}$and $\mathrm{PO}_{4}^{3-} / \mathrm{N}^{-} \mathrm{NH}_{4}^{+}$were mainted at 8.68 and 0.22 , respectively. Three trace elements solutions, $0.75 \mathrm{ml} \mathrm{l}^{-1}$ of solution $\mathrm{A}\left(20 \mathrm{mg} \mathrm{l}^{-1} \mathrm{ZnSO}_{4} .7 \mathrm{H}_{2} \mathrm{O}\right.$, $20 \mathrm{mg} \mathrm{l}^{-1} \mathrm{CuSO}_{4} .5 \mathrm{H}_{2} \mathrm{O}$ and $20 \mathrm{mg} \mathrm{l}^{-1} \mathrm{Na}_{2} \mathrm{MoO}_{4} \cdot 2 \mathrm{H}_{2} \mathrm{O}$ ), $0.75 \mathrm{ml} \mathrm{l}^{-1}$ of solution B $\left(2 \mathrm{mg} \mathrm{l}^{-1} \mathrm{MgSO}_{4} .7 \mathrm{H}_{2} \mathrm{O}\right)$ and $3.75 \mathrm{ml} \mathrm{l}^{-1}$ of solution $\mathrm{C}\left(1.44 \mathrm{~g} \mathrm{l}^{-1} \mathrm{FeSO}_{4} .7 \mathrm{H}_{2} \mathrm{O}\right.$ and $2.06 \mathrm{~g}$ $1^{-1}$ EDTA) were supplied in order to stimulate nitrifying bacteria activity [10]. The temperature was controlled at $25 \pm 1{ }^{\circ} \mathrm{C}$ for the first 10 months of operation and afterwards to $29 \pm 1{ }^{\circ} \mathrm{C}$. The $\mathrm{pH}$ average value of the reactor during the first 180 days was within the range of 6.5-7.6 and after that it was controlled at $7.5 \pm 0.2$ with sodium hydrogenocarbonate $50 \mathrm{~g} \mathrm{l}^{-1} \mathrm{NaHCO}_{3}$.

\section{Pilot scale reactor operation}

The reactor was seeded in batch operation with activated sludge according to a specific start-up procedure [11]. Municipal wastewater after secondary treatment was used as reactor influent in continuous operation. The reactor was operated under conditions of step-wise increase of the secondary effluent flow rate. Average influent ammonia and chemical oxygen demand were $50 \mathrm{mgN}-\mathrm{NH}_{4}^{+} \mathrm{l}^{-1}$ and $53 \mathrm{mgO}_{2} \mathrm{l}^{-1}$, respectively. The temperature was within the range of $16.7-22.5^{\circ} \mathrm{C}$ and the $\mathrm{pH}$ had an average value between 6.9 and 7.8 .

\section{2}

\section{Analytical procedures}

Ammonia, nitrite and nitrate were evaluated photometrically, immediately after sampling and filtration through $0.22 \mu \mathrm{m}$ membranes, by spectrophotometer HITACHI U100 according to Standard Methods [12], procedures 4500$\mathrm{NH}_{3} \mathrm{C}, 4500-\mathrm{NO}_{2} \mathrm{~B}$ and $4500-\mathrm{NO}_{3} \mathrm{~B}$, respectively. The dissolved oxygen concentration was measured by an oxymeter WTW, model OXI 538.

The quantity of washed out biomass in the effluent was determined as total suspended solids after filtration by $0.22 \mu \mathrm{m}$ filter, according to Standard Methods [12], procedure $2540 \mathrm{~B}$. The biofilm mass was estimated by means of total protein (TP) and by dry matter (DM) measurements. The biofilm was removed from the support medium after 7.5 minutes ultrasound treatment in $30 \mathrm{~s}$ cycles. The biomass TP was measured according to the method of Lowry [11]. Biomass DM was determined by the gravimetric method. 
Table 1. Geometry and operating conditions of the circulating bed reactors

\begin{tabular}{|c|c|c|}
\hline Parameters & Laboratory scale reactor & Pilot scale reactor \\
\hline Liquid volume $\left(\mathrm{m}^{3}\right)$ & 0.0046 & 4.6 \\
\hline Width = Length (m) & 0.09 & 0.9 \\
\hline Height (m) & 0.6 & 6 \\
\hline Superficial air velocity $\left(\mathrm{m} \mathrm{s}^{-1}\right)$ & 0.02 & $0.024-0.031$ \\
\hline Hydraulic residence time (h) & 1.0 & from 2.3 to 0.5 \\
\hline Loading rate $\left(\mathrm{KgN}-\mathrm{NH}_{4}^{+} \mathrm{m}^{-3} \mathrm{~d}^{-1}\right)$ & 1.19 & $0.5-2.5$ \\
\hline
\end{tabular}

Biomass density represents the weight of biomass expressed as DM per unit volume of biofilm. Biofilm volume was measured using a pycnometer as follows: the difference in the mass of acetone weighted in a pycnometer containing support particles with and without biofilm, divided by the acetone density.

Biofilm scanning electron microscopy (SEM) observations were made after adequate preparation of the bioparticles. After sampling, the biofilm cells were fixed with a solution of $3 \%(\mathrm{v} / \mathrm{v})$ glutaraldehyde prepared in cacodylate buffer $\mathrm{pH} 7.2$ for $2 \mathrm{~h}$. Subsequently they were submitted to dehydration in a graded ethanol series $(30,50,70,90$ and $100 \%)$. The samples were gold coated before they were observed in a Leica Cambridge scanning electron microscope.

\section{3}

\section{Effect of dissolved oxygen concentration on the nitrification rate}

\section{Laboratory scale reactor}

The effect of dissolved oxygen concentration $(D O)$ on the nitrification rate was investigated in short term experiments (10-12 hours), with constant biomass concentration. The $D O$ was manipulated by changing the oxygen content of the gas, while keeping the superficial gas velocity constant at $0.02 \mathrm{~m} \mathrm{~s}^{-1}$. This was obtained by mixing pressurized air and nitrogen or oxygen gas. The influence of the $D O$ on the nitrification rate was also evaluated in long term reactor operation at constant air flow rate and ammonia loading rate.

\section{Pilot scale reactor}

The effect of $D O$ on the nitrification rate was investigated in short term experiments (2-3 hours), with constant biomass concentration. The $D O$ in the reactor was manipulated by changing the air flow rate. The influence of the $D O$ on the nitrification rate was also evaluated in long term reactor operation at constant bulk oxygen concentration and varying ammonia loading rate.

\section{4}

\section{Oxygen transfer coefficient $\left(k_{L} a\right)$ measurement}

The overall oxygen transfer coefficient $\left(k_{L} a\right)$ can be calculated by means of a direct method [13]. Under steady state conditions the overall oxygen balance over the reactor yields:

$$
\begin{aligned}
\mathrm{d} C_{L, \mathrm{O}_{2}} / \mathrm{d} t= & k_{L} a\left(C_{L, 2}^{*}-C_{L, \mathrm{O}_{2}}\right)-r_{\mathrm{O}_{2}} \\
& \text { where } \mathrm{d} C_{L, \mathrm{O}_{2}} / \mathrm{d} t=0,
\end{aligned}
$$

i.e.:

$k_{L} a=r_{\mathrm{O}_{2}} /\left(C_{L, \mathrm{O}_{2}}^{*}-C_{L, \mathrm{O}_{2}}\right)$,

where $C_{L, \mathrm{O}_{2}}^{*}$ is the dissolved oxygen concentration at saturation conditions. The actual dissolved oxygen concentration $\left(C_{L, \mathrm{O}_{2}}\right)$ was measured with an oxygen electrode, whereas the oxygen conversion rate $\left(r_{\mathrm{O}_{2}}\right)$ was calculated from the measured nitrite $\left(r_{\mathrm{N}-\mathrm{NO}_{2}^{-}}\right)$and nitrate $\left(r_{\mathrm{N}-\mathrm{NO}_{3}^{-}}\right)$ conversion rates using the stoichiometric constants for ammonia (taken as $4.57 \mathrm{gO}_{2} / \mathrm{gN}^{-\mathrm{NH}_{4}^{+}}$) and nitrite (taken as $3.43 \mathrm{gO}_{2} / \mathrm{gN}^{-\mathrm{NH}_{2}^{-}}$) oxidation:

$r_{\mathrm{O}_{2}}=3.43 r_{\mathrm{N}-\mathrm{NO}_{2}^{-}}+4.57 r_{\mathrm{N}-\mathrm{NO}_{3}^{-}}$.

\section{3}

\section{Results and discussion}

\section{1}

\section{Biofilm development}

Biofilm development, observed by light and scanning electron microscopes can be described as a three phase process of (i) cell attachment, (ii) biofilm formation on the concavities of the support medium (non homogeneous coverage of the support by the biofilm), and (iii) biofilm spreading from the colonized surfaces areas to the remaining surface until all the support medium is completely covered by the biofilm (homogeneous coverage). Phases (i), (ii) and (iii) are presented in Fig. 2. This process was similar to the one described by Heijnen [14].

Biofilm growth curves expressed by total protein (TP) and chemical oxygen demand (COD) are shown in Fig. 3, for the laboratory and pilot scale reactors. The biofilm accumulation rate was higher during the start-up period of the laboratory scale reactor. After 100 days of reactor operation, biofilm total protein steady-state concentration was reached and had an average value of $0.91 \mathrm{kgTP}$ $\mathrm{m}^{-3}$ reactor. In the pilot scale reactor, biofilm steady state composition was not attained because the reactor operation was changed to secondary nitrification after day 90 . It can be observed an increase in the biofilm accumulation rate expressed by COD compared to the one expressed by total protein after 60 days of pilot reactor operation. This fact can be related to the accumulation of inert materials in the biofilm [15].

\section{2}

The effect of oxygen concentration on the nitrification rate At laboratory scale, experiments were carried out during continuous reactor operation at conditions of $\mathrm{pH}$ not controlled (first 180 days) and $\mathrm{pH}$ controlled, to study the 

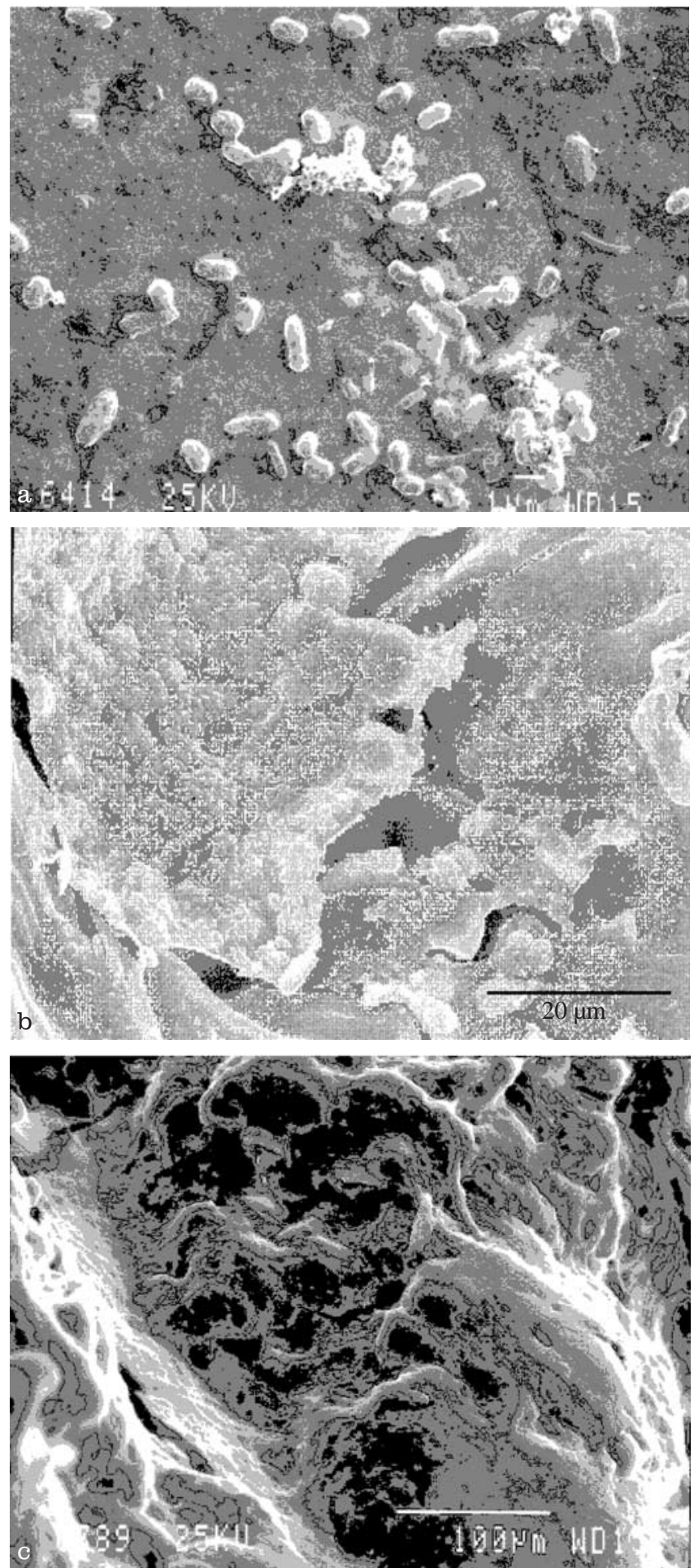

Fig. 2a-c. Scanning electron microscopy photographs for support medium with: $\mathbf{a}$ adhered individuals cells, $\mathbf{b}$ non homogeneous coverage and $\mathrm{c}$ homogeneous coverage by the biofilm

influence of dissolved oxygen on nitrification kinetics. Steady state results from the laboratory scale reactor, for both conditions, and from the pilot scale reactor are summarized in Table 2.

Figure 4 shows the specific ammonia removal rate as a function of dissolved oxygen concentration on logarithm
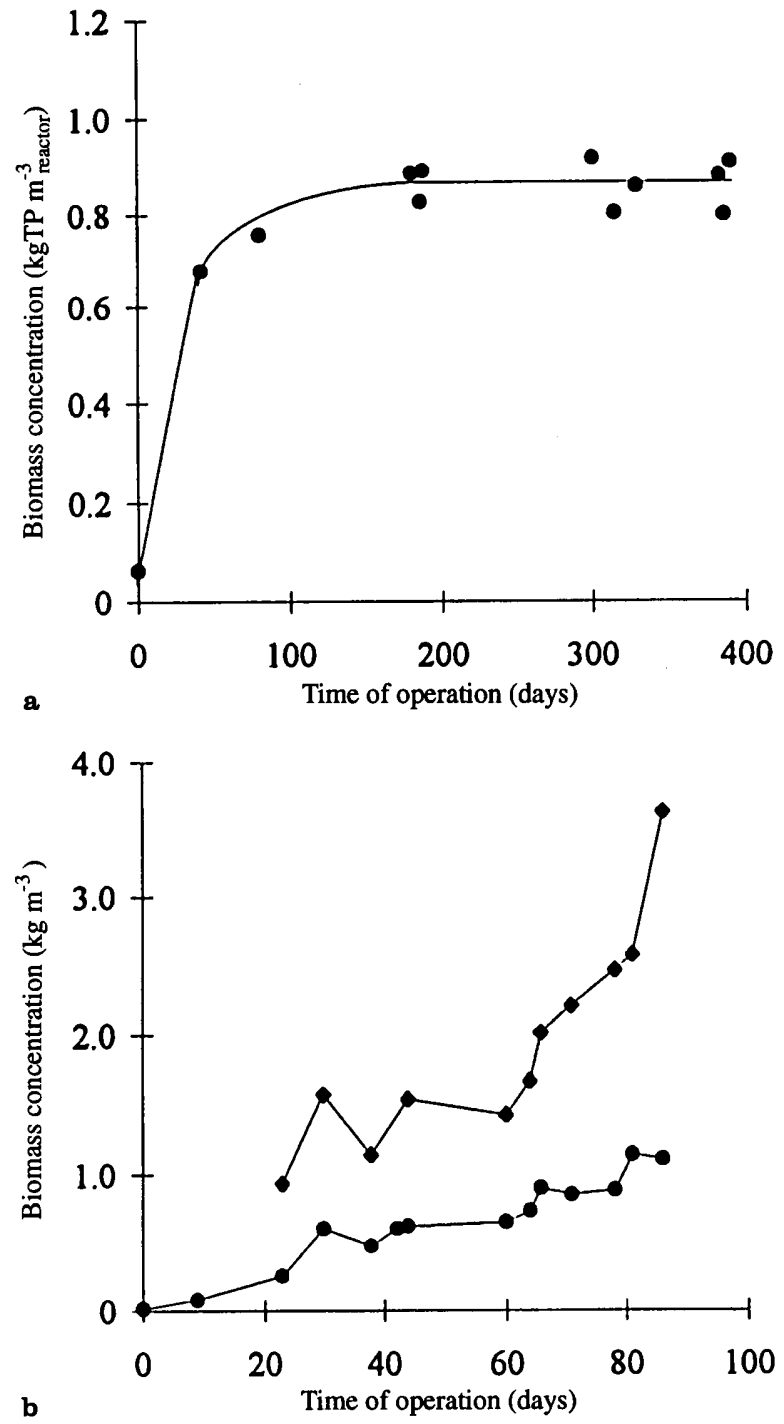

Fig. 3a,b. Nitrifying biofilm growth: a laboratory scale reactor, b pilot scale reactor. Symbols: $\bullet$, Total Protein; $\bullet$, COD

scale for the two operating conditions of the laboratory scale reactor: with and without $\mathrm{pH}$ control. It is evident from the figure that for both operating conditions, the specific ammonia removal rate depends on the bulk oxygen concentration, and a linear dependency is found until it reaches a constant value. The slope of both curves was calculated as 0.5 .

The theory put forward by Harremöes [2] based on the diffusion-reaction model in porous catalysts is used here. Due to the highly turbulent conditions, liquid phase mass transfer is not considered to be the rate limiting step. When oxygen is partly penetrating the biofilm, the removal rate is governed by a half order kinetics according to Eq. (4a). The oxygen removal rate is expected to increase proportionally to the square root of the bulk concentration, until the maximum removal rate is achieved, the latter being given by Eq. (5):

$r_{a \mathrm{~N}}=\left(1 / v_{\mathrm{O}_{2} / \mathrm{N}}\right) \times k_{1 / 2 \mathrm{aO}_{2}} \times \sqrt{C_{L, \mathrm{O}_{2}}}$,

where: 
Table 2. Steady-state operating conditions of laboratory and industrial scale reactors

\begin{tabular}{|c|c|c|c|}
\hline & \multicolumn{2}{|l|}{ Laboratory scale } & \multirow[t]{2}{*}{ Pilot scale } \\
\hline & $\mathrm{pH}$ not controlled & $\mathrm{pH}$ controlled & \\
\hline $\begin{array}{l}\text { Removal rate } \\
\left(\mathrm{kgN}-\mathrm{NH}_{4}^{+} \mathrm{m}^{-3} \mathrm{~d}^{-1}\right.\end{array}$ & 0.63 & 1.14 & 1.63 \\
\hline $\begin{array}{l}\mathrm{N}-\mathrm{NH}_{4}^{+} \text {removal efficiency } \\
\text { Biomass concentration }\end{array}$ & $64 \%$ & $>95 \%$ & $>95 \%$ \\
\hline$\left(\mathrm{kgPT}_{\text {reactor }}^{-3}\right)$ & 0.72 & 0.91 & 0.89 \\
\hline$\left(\mathrm{kgDM} \mathrm{m}_{\text {reactor }}^{-3}\right)$ & 1.47 & 2.85 & 1.57 \\
\hline Biomass residence time $(\mathrm{d})$ & 10.8 & 20.1 & - \\
\hline $\begin{array}{l}\text { Specific activity } \\
\left(\operatorname{kgN}^{-\mathrm{NH}_{4}^{+}} \mathrm{kgPT}^{-1} \mathrm{~d}^{-1}\right)\end{array}$ & 0.93 & 1.29 & 1.90 \\
\hline 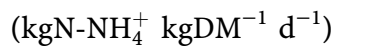 & 0.43 & 0.40 & 0.60 \\
\hline
\end{tabular}

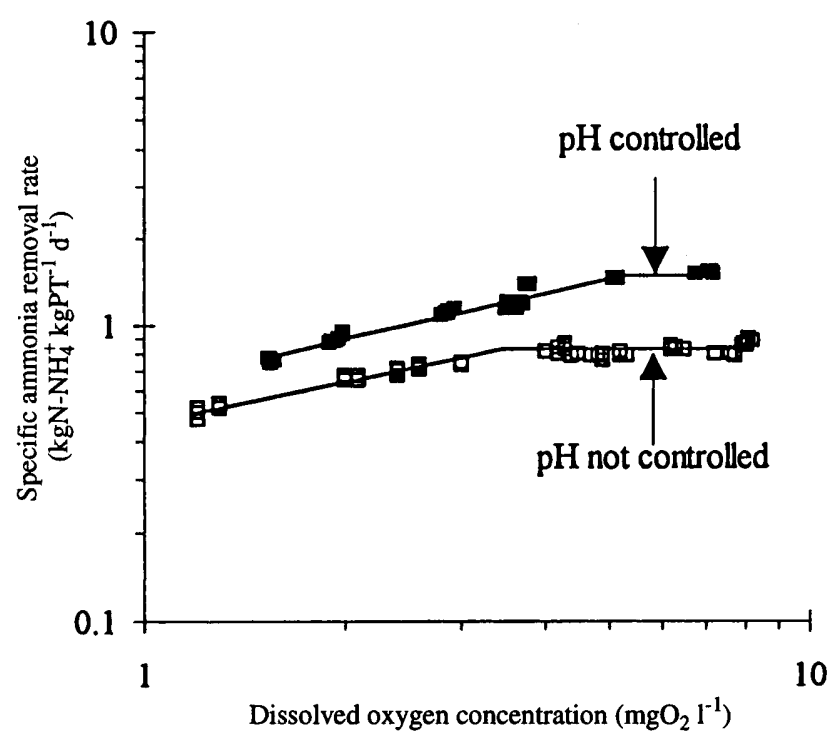

Fig. 4. Specific ammonia removal rate as a function of dissolved oxygen concentration in the laboratory scale reactor for the two operating conditions. $\mathrm{pH}$ not controlled and $\mathrm{pH}$ controlled

$k_{1 / 2 \mathrm{aO}_{2}}=\sqrt{2 \times D_{\mathrm{fO}_{2}} \times v_{\mathrm{O}_{2} / \mathrm{N}} \times k_{0 \mathrm{f}_{\mathrm{N}}}}$.

$r_{a_{\mathrm{N}}}=k_{0 \mathrm{a}_{\mathrm{N}}}=k_{0 \mathrm{f}_{\mathrm{N}}} \times L_{\mathrm{f}}$,

where $r_{a_{\mathrm{N}}}=$ nitrification rate $\left(\mathrm{gN}-\mathrm{NH}_{4}^{+} \mathrm{m}^{-2} \mathrm{~d}^{-1}\right) ; v_{\mathrm{O}_{2} / \mathrm{N}}$ $=$ stoichiometric constant for ammonia oxidation (taken as $\left.4.57 \mathrm{mgO}_{2} / \mathrm{mgN}^{-\mathrm{NH}_{4}^{+}}\right) ; C_{L, \mathrm{O}_{2}}=$ bulk oxygen concentration $\left(\mathrm{mgO}_{2} 1^{-1}\right) ; k_{1 / 2 \mathrm{aO}_{2}}=$ apparent half order oxygen rate constant $\left(\mathrm{gO}_{2}^{0.5} \mathrm{~m}^{-0.5} \mathrm{~d}^{-1}\right) ; k_{0 \mathrm{a}_{\mathrm{N}}}=$ apparent zero order ammonia rate constant $\left(\mathrm{gN}-\mathrm{NH}_{4}^{+} \mathrm{m}^{-2} \mathrm{~d}^{-1}\right)$; $k_{0_{\mathrm{N}}}=$ intrinsic rate constant $\left(\mathrm{gN}-\mathrm{NH}_{4}^{+} \mathrm{m}^{-3} \mathrm{~d}^{-1}\right)$; $D_{\mathrm{fO}_{2}}=$ oxygen diffusion coefficient in the biofilm $\left(\mathrm{m}^{2}\right.$ $\left.\mathrm{s}^{-1}\right) ; L_{\mathrm{f}}=$ biofilm thickness $(\mathrm{m})$.

Values of the biofilm apparent constants obtained by fitting Eqs. (4a) and (5) to the experimental results are summarized in Table 3.

As can be seen in Table 3, two different half order oxygen rate constants were determined. The half order oxygen rate constant for the case where the $\mathrm{pH}$ was controlled is almost $100 \%$ higher than for the case where the $\mathrm{pH}$ was not controlled. This discrepancy can be related with the increase of the ammonia removal rate during continuous reactor operation due to $\mathrm{pH}$ control [16]. Other authors using the half order reaction concept re-
Table 3. Biofilm apparent constants for the laboratory scale reactor

\begin{tabular}{|c|c|c|}
\hline \multirow[t]{2}{*}{ Kinetic constants } & \multicolumn{2}{|c|}{ Laboratory scale } \\
\hline & $\begin{array}{l}\mathrm{pH} \text { not } \\
\text { controlled }\end{array}$ & $\begin{array}{l}\mathrm{pH} \\
\text { controlled }\end{array}$ \\
\hline Zero order constant $\left(K_{0 a_{N}}\right)$ & & \\
\hline$\left(\mathrm{kgN}-\mathrm{NH}_{4}^{+} \mathrm{kgPT}^{-1} \mathrm{~d}^{-1}\right)$ & 0.83 & 1.5 \\
\hline$\left(\mathrm{gN}-\mathrm{NH}_{4}^{+} \mathrm{m}^{-2} \mathrm{~d}^{-1}\right)$ & 0.85 & 2.1 \\
\hline $\begin{array}{l}\text { Half order constant }\left(k_{1 / 2 a O_{2}}\right) \\
\left(\mathrm{gO}_{2}^{0.05} \mathrm{~m}^{-0.5} \mathrm{~d}^{-1}\right) \\
\text { Oxygen transition value }\end{array}$ & 2.2 & 4.0 \\
\hline $\begin{array}{l}\left(\mathrm{mgO}_{2} \mathrm{l}^{-1}\right) \\
\text { Oxygen/Ammonia ratio at transition }\end{array}$ & 3.4 & 5.2 \\
\hline$\left(\mathrm{gO}_{2} \mathrm{~g}^{-1} \mathrm{~N}-\mathrm{NH}_{4}^{+}\right)$ & - & $1.5-2$ \\
\hline
\end{tabular}

ported apparent constants for several types of biofilm reactors. These values are summarized in Table 4 .

The apparent zero order and half order rate constants determined in this study are within the range of values reported in literature (Table 4). Some authors presented different values of the half order rate constant, depending on the dissolved oxygen concentration in the reactor [6] and on the fraction of autotrophs in the biofilm [3]. The half order rate constant determined in this study is in the upper limit of the range of values reported in the literature. The reason for this could be related to the hydrodynamic characteristics of the CBR, that ensures a good mass transfer and effective control of biofilm thickness [17], enhancing the oxygen transport into the biofilm.

Hem et al. [5] studied nitrification in a moving bed biofilm reactor (MBBR) as a function of the oxygen concentration and the kinetics obtained was close to a first order reaction, indicating a possible significant influence of the liquid film resistance on the biofilm kinetics. Rusten et al. [18] suggested that the reason why liquid film diffusion was important in the MBBR was related with the carrier used. They demonstrated that only the protected surfaces inside the carrier were available for biofilm growth.

The oxygen diffusion coefficient determined in the present work using Eq. (6), $1.75 \times 10^{-9} \mathrm{~m}^{2} \mathrm{~s}^{-1}$, was obtained by fitting the diffusion-reaction model, Eqs. (4b) and (5), to the rate of ammonia consumption as a function of oxygen concentration for the case where the $\mathrm{pH}$ was controlled: 
Table 4. Nitrifying biofilm kinetic constants

\begin{tabular}{|c|c|c|c|}
\hline Biofilm Reactor & $\begin{array}{l}k_{0 a_{N}} \\
\left(\mathrm{gN}-\mathrm{NH}_{4}^{+} \mathrm{m}^{-2} \mathrm{~d}^{-1}\right)\end{array}$ & $\begin{array}{l}k_{1 / 2 a O_{2}} \\
\left(\mathrm{gO}_{2}^{0.5} \mathrm{~m}^{-0.5} \mathrm{~d}^{-1}\right)\end{array}$ & References \\
\hline $\begin{array}{l}\text { Rotating Disc System } \\
\left(1-30 \mathrm{mgO}_{2} \mathrm{l}^{-1}\right) \\
\text { Floating Filter } \\
\left(1-7 \mathrm{mgO}_{2} \mathrm{l}^{-1}\right) \\
\text { Moving Bed Biofilm Reactor } \\
\left(1-15 \mathrm{mgO}_{2} \mathrm{l}^{-1}\right) \\
\text { Submerged Aerated Filter } \\
\left(4-5 \mathrm{mgO}_{2} \mathrm{l}^{-1}\right) \\
\left(2-3 \mathrm{mgO}_{2} \mathrm{l}^{-1}\right) \\
\text { Circulating Bed Reactor } \\
\left(1-7.2 \mathrm{mgO}_{2} \mathrm{l}^{-1}\right)\end{array}$ & $\begin{array}{l}0.8-4 \\
1.7 \\
0.7-1 \\
1.82 \\
0.47 \\
2.1\end{array}$ & $\begin{array}{l}2.08-3.76 \\
2.8-2.9 \\
- \\
2.7 \\
1.4 \\
4.0\end{array}$ & $\begin{array}{l}{[3]} \\
{[4]} \\
{[5]} \\
{[6]}\end{array}$ \\
\hline
\end{tabular}

Table 5. Measured oxygen diffusion coefficient within biofilms

\begin{tabular}{|c|c|c|c|c|}
\hline Method & $D_{\mathrm{fO}_{2}} \times 10^{-9}$ & $D_{\mathrm{fO}_{2}} / D_{\mathrm{W}, \mathrm{O}_{2}}$ & Biomass type & References \\
\hline Diffusion cell & $\begin{array}{l}2.5 \\
\left(20^{\circ} \mathrm{C}, \mathrm{pH}=7\right)\end{array}$ & 1.21 & $\begin{array}{l}\text { Filtered } \\
\text { microbial layer }\end{array}$ & {$[22]$} \\
\hline Diffusion cell & $\begin{array}{l}2.05 \\
\left(20^{\circ} \mathrm{C}, \mathrm{pH}=7.8\right)\end{array}$ & 0.97 & $\begin{array}{l}\text { Filtered } \\
\text { microbial layer }\end{array}$ & [23] \\
\hline $\begin{array}{l}\text { Diffusion reaction } \\
\text { model }\end{array}$ & $\begin{array}{l}1.75 \\
\left(29^{\circ} \mathrm{C}, \mathrm{pH}=7.5\right)\end{array}$ & 0.66 & $\begin{array}{l}\text { Nitrifying } \\
\text { biofilm }\end{array}$ & This study \\
\hline
\end{tabular}

The diffusivity of oxygen in water $\left(D_{\mathrm{w}, \mathrm{O}_{2}}\right)$ was obtained from the Wilke-Change correlation [24]

$D_{\mathrm{fO}_{2}}=\left(k_{1 / 2 \mathrm{aO}_{2}}^{2} / 2 k_{0 \mathrm{aO}_{2}}\right) \times L_{\mathrm{f}}$.

The average biofilm thickness used in the determination of the oxygen diffusion coefficient, $179 \mu \mathrm{m}$, was calculated from the quotient between the biofilm dry matter per unit surface area of the support and the biofilm dry density. The biofilm dry density was experimentally measured as $28.3 \mathrm{kgDM} \mathrm{m}^{-3}$ wet biofilm and the biofilm dry matter per unit surface area of the support was obtained from the quotient between the biofilm dry matter per unit support volume, which was experimentally measured as $13.5 \mathrm{kgDM}$ $\mathrm{m}^{-3}$ support , and the specific surface area of the support $\left(2670 \mathrm{~m}^{2} \mathrm{~m}^{-3}\right)$. The oxygen diffusion coefficient calculated $\left(1.75 \times 10^{-9} \mathrm{~m}^{2} \mathrm{~s}^{-1}\right)$ was around $66 \%$ of the respective value in water.

Several authors reported values of diffusion coefficients of compounds in biofilms, in microbial cell aggregates and in gels with immobilized cells [19-21]. However, literature on the determination of the oxygen diffusion coefficient in nitrifying biofilms is scarce. Directly measured values of the oxygen diffusion coefficient reported in literature for mixed nitrifying biofilms are presented in Table 5, together with the values obtained in this study.

The oxygen diffusion coefficient determined in the present work (Table 4) is lower than the values published by other authors, probably due to the different methods that have been used. In the diffusion cell method a microbial layer was made by filtering a dispersed nitrifying culture onto the support filter, and oxygen was allowed to diffuse through the prepared biomass layer from a chamber with a high oxygen concentration to another one which was previously deoxygenated $[22,23]$. However, inherent inaccuracies in the experimental method can be mentioned. Filtered biomass would not have the same structure as a true biofilm and the mass transfer effect of the rough surface of the grown biofilm may be lost. The method used in the present work requires the determination of the specific surface area of the biofilm particles. Since the biofilm was developed in an irregular granular support, the experimental measurement of this parameter was difficult and a simplification was made by considering that the biofilm particle had a spherical shape.

In order to compare the quotient of effective oxygen diffusivity in the biofilm to molecular oxygen diffusivity in water obtained in this work with those reported in literature (Table 5), the same correlation was used to determine the molecular oxygen diffusivity in water (Wilke-Change correlation, [24]). The quotient value obtained by Williamson and McCarty [22], indicating that the oxygen diffusivity in the biofilm is higher than the molecular oxygen diffusivity in water, seems to indicate that another mechanism was involved in the transport of oxygen in the "biofilm". However, no comment was made by the authors about this value.

Nitrate accumulation was not detected in the effluent from the laboratory scale reactor for both operating conditions: $\mathrm{pH}$ not controlled and $\mathrm{pH}$ controlled. For the phase where the $\mathrm{pH}$ was not controlled, the effluent nitrite was 0.47 mgN-NO ${ }_{2}^{-} 1^{-1}$ and ammonia removal efficiency was $64 \%$. An effluent nitrite of $0.81 \mathrm{mgN}^{-\mathrm{NO}_{2}^{-}} \mathrm{l}^{-1}$ and ammonia removal efficiency higher than $95 \%$ was observed for the phase where the $\mathrm{pH}$ was controlled. Dissolved oxygen in the reactor was always higher than $3.5 \mathrm{mgO}_{2} \mathrm{l}^{-1}$. This implies that oxygen did not limit the nitrification rate. 


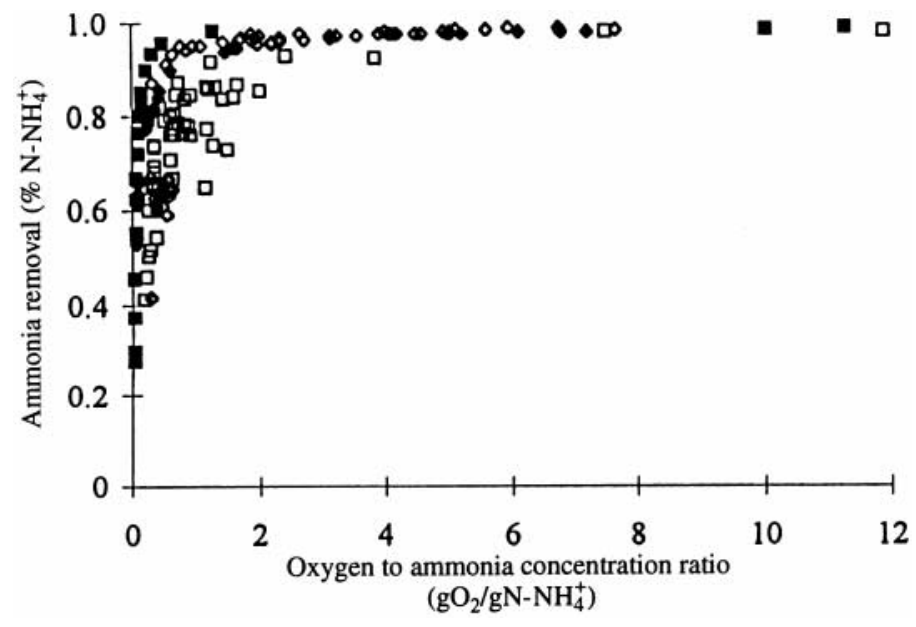

Fig. 5. Ammonia removal as a function of bulk oxygen to ammonia effluent concentration ratio in the laboratory and pilot scale reactors. Symbols: $\diamond$, lab scale (short term); $\bullet$, lab scale (long term); $\mathbf{\square}$, pilot scale (short term); $\square$, pilot scale (long term)

\section{3}

The phenomenon of either the ammonia or the oxygen concentration being limiting for the nitrification rate

According to the experimental results obtained in the laboratory scale reactor, the dissolved oxygen concentration for which a change in the order of reaction was observed, i.e. half order reaction to zero order reaction, depended on the $\mathrm{pH}$ control (Fig. 4). The transition values were 3.4 and $5.2 \mathrm{mgO}_{2} \mathrm{l}^{-1}$ (Table 3), for the cases of $\mathrm{pH}$ not controlled and $\mathrm{pH}$ controlled, respectively.

Figure 5 presents the ammonia removal efficiency as a function of bulk oxygen to ammonia ratio for the laboratory and pilot scale reactors. Results were obtained from two sets of experiments: long term (several months) and short term (some hours) experiments. For both reactors, the transition from ammonia limitation to oxygen limitation was found to occur when the bulk oxygen to ammonia ratio was about $1.5-2 \mathrm{gO} 2 / \mathrm{gN}-\mathrm{NH}_{4}^{+}$. It seems that reactor scale up did not affect the transition value from ammonia limitation to oxygen limitation.

Values reported in the literature for the transition from ammonia rate limited to oxygen limited nitrification are within the range $2.5-4 \mathrm{gO}_{2} / \mathrm{gN}-\mathrm{NH}_{4}^{+}[3,5,6,22]$. The value obtained in this work for the laboratory and pilot scale reactors is lower than the values obtained by other authors. Again it can be suggested that due to the hydrodynamic characteristics of the CBR and the resulting thin biofilms, the resistance to oxygen mass transfer within the biofilm is lower than the observed in other biofilm reactors.

\section{4}

\section{Oxygen mass transfer}

The volumetric oxygen mass transfer coefficient, $k_{L} a$, in the laboratory scale reactor presented a constant value of $0.017 \mathrm{~s}^{-1}$ for both phases of reactor operation, with and without $\mathrm{pH}$ control, corresponding to different efficiencies of ammonia nitrogen removal in the reactor, $64 \%$ and $>95 \%$, respectively. This can be explained according to Eq. (2) by the increase on the ammonia nitrogen removal rate due to $\mathrm{pH}$ control that resulted in a decrease on the dissolved oxygen concentration in the reactor from $7.1 \mathrm{mgO}_{2}$ $\mathrm{l}^{-1}$ to $4.7 \mathrm{mgO}_{2} \mathrm{l}^{-1}$. Fig. 6 provides $k_{L} a$ as a function of

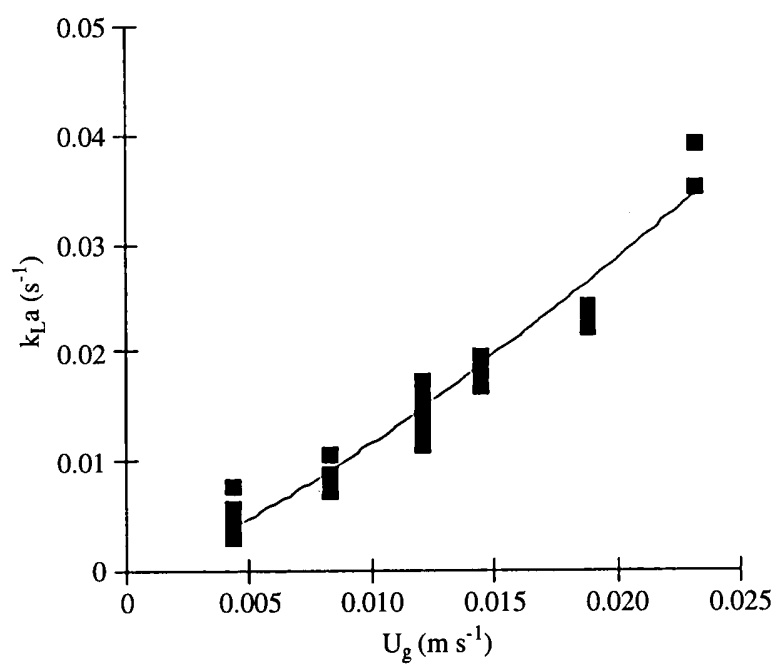

Fig. 6. $k_{L} a$ as a function of superficial air velocity $\left(U_{\mathrm{g}}\right)$ in the laboratory scale reactor

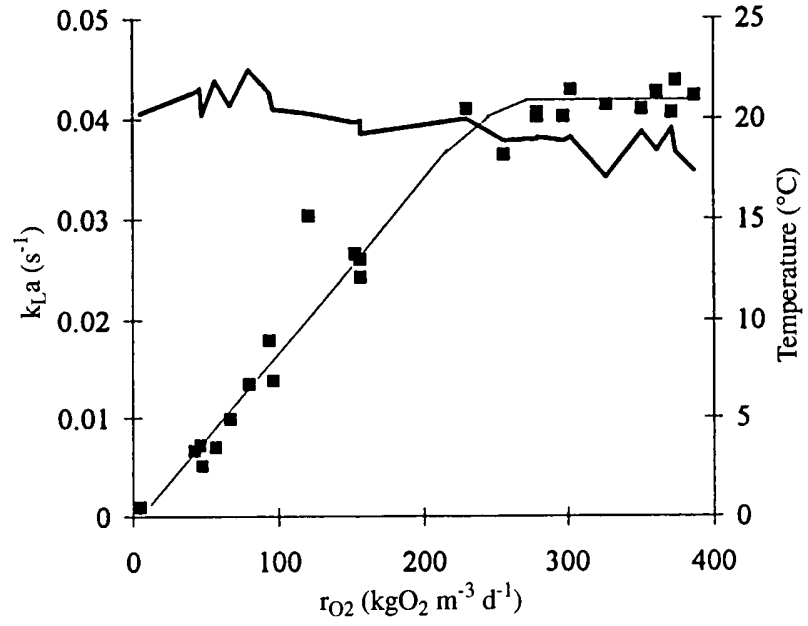

Fig. 7. $k_{L} a$ and temperature as a function of oxygen conversion rate $\left(\mathrm{r}_{\mathrm{O} 2}\right)$ in the pilot scale reactor. Symbols: $k_{L} a$,-temperature 
superficial air velocity $\left(U_{\mathrm{g}}\right)$. It was found that $k_{L} a$ is a power function of $U_{\mathrm{g}}$ in the range of $0.004-0.023 \mathrm{~m} \mathrm{~s}^{-1}$.

Figure 7 shows the $k_{L} a$ and the dissolved oxygen concentration as a function of the oxygen conversion rate $\left(r_{\mathrm{O}_{2}}\right)$ in the pilot scale reactor. For $r_{\mathrm{O}_{2}}$ values in the range of 0.12 to $4.8 \mathrm{kgO}_{2} \mathrm{~m}^{-3} \mathrm{~d}^{-1}, k_{L} a$ increased with $r_{\mathrm{O}_{2}}$, because the dissolved oxygen concentration in the reactor was kept constant. For $r_{\mathrm{O}_{2}}$ values higher than $4.8 \mathrm{kgO}_{2} \mathrm{~m}^{-3} \mathrm{~d}^{-1}, k_{L} a$ presented a constant value $(0.040$ $\mathrm{s}^{-1}$ ) because the temperature dropped and therefore, the dissolved oxygen concentration at saturation increased.

In another work performed on this reactor operating in tertiary nitrification, $k_{L} a$ was measured by means of the gas-off method [11]. The average value obtained $0.043 \mathrm{~s}^{-1}$, agreed with the one obtained in the present work, $0.040 \mathrm{~s}^{-1}$. Also, a $k_{L} a$ value was calculated by means of an equation relating the $k_{L} a$ with the superficial air velocity in the absence of biofilm on the support particles, proposed by Lazarova et al. [11]: $k_{L} a\left(h^{-1}\right)=\left(1.7 \times 10^{6}\right)$ $\times U_{\mathrm{g}}\left(\mathrm{m} \mathrm{s}^{-1}\right)^{2.66}$. For a superficial air velocity of $0.031 \mathrm{~m} \mathrm{~s}^{-1}$ the $k_{L} a$ calculated was $0.046 \mathrm{~m} \mathrm{~s}^{-1}$. This value is similar to the ones obtained by the two experimental methods and it can be suggested that the mass transfer coefficient did not change significantly after biofilm development compared to the situation without biofilm. The growth of biofilm on the support particles did not change its volume fraction in the reactor. Furthermore, the previous equation adequately describes oxygen mass transfer in the laboratory scale reactor.

The average $k_{L} a$ value obtained in this work for pilot scale reactor, $0.040 \mathrm{~s}^{-1}$, is higher than the $k_{L} a$ value obtained in the laboratory scale reactor, $0.017 \mathrm{~s}^{-1}$. This is due to the different superficial air velocities at which the two reactors were operated, $0.031 \mathrm{~m} \mathrm{~s}^{-1}$ and $0.02 \mathrm{~m} \mathrm{~s}^{-1}$ for the pilot and laboratory scale reactors, respectively.

\section{4}

\section{Conclusion}

The following conclusions can be drawn from the present study:

1. The biofilm development can be described as a three phase process of cell attachment, biofilm formation on the concavities of the support particles (non homogeneous coverage of the support by the biofilm), and biofilm spreading from the colonized surface areas to the remaining surface area until all the support medium is completely covered by the biofilm (homogeneous coverage).

2. The nitrification kinetics of the laboratory CBR as a function of the oxygen concentration follows the half and zero order rate equations of the diffusion reaction model. When oxygen was the rate limiting substrate, the nitrification rate was close to a half order function of the oxygen concentration. The oxygen diffusion coefficient estimated by fitting the diffusion-reaction model to the experimental results was around $66 \%$ of the respective value in water.

3. The transition from ammonia limitation to oxygen limitation was found to occur when the bulk oxygen/ ammonia ratio was within the range 1.5-2 $\mathrm{gO}_{2} / \mathrm{gN}^{-\mathrm{NH}_{4}^{+}}$ for the laboratory and pilot scale reactors.
4. The volumetric oxygen mass transfer coefficient $\left(k_{L} a\right)$ determined in the laboratory scale reactor was $0.017 \mathrm{~s}^{-1}$ for a superficial air velocity of $0.02 \mathrm{~m} \mathrm{~s}^{-1}$, and determined in the pilot scale reactor was $0.040 \mathrm{~s}^{-1}$ for a superficial air velocity of $0.031 \mathrm{~m} \mathrm{~s}^{-1}$. The $k_{L} a$ for the pilot scale reactor did not change significantly after biofilm development compared to the value measured without biofilm.

\section{References}

1. De Beer, B.; Van Den Heuvel, J.C.; Ottengraf, S.P.P.: Microelectrode measurements of the activity distribution in nitrifying bacteria aggreagates. Appl. Environ. Microbiol. 59 (1993) 573-579

2. Harremöes P.: Biofilm Kinetics. In: Mitchell, R. (Ed.): Water Pollution Microbiology, vol. 2, New York: John Wiley \& sons 1978 pp. 82-109

3. Gönenç I.E.; Harremöes P.: Nitrification in rotating disk systems - I, Criteria for transition from oxygen to ammonia rate limitation. Wat. Res. 19 (1985) 1119-1127

4. Toettrup, H.; Rogalla, F.; Vidal, A.; Harremöes, P.: The treatment trilogy of floating filters: from pilot to prototype to plant. Wat. Sci. Tech. 29 (1994) 23-32

5. Hem, L.J.; Rusten, B.; Ødegaard,H.: Nitrification in a moving bed biofilm reactor. Wat. Sci. Tech. 28 (1994) 1425-1433

6. Çeçen, F.; Gönenç, I.E.: Nitrogen removal characteristics of nitrification and denitrification filters. Wat. Sci. Tech. 29 (1994) 409-416

7. Tanaka, H.; Dunn, I.J.: Kinetics of biofilm nitrification. Bitotech Bioeng. 24 (1982) 669-689

8. Tijhuis, L.; Huisman, J.L.; Hekkelman, H.D.; van Loosdrecht, M.C.M.; Heijnen, J.J.: Formation of nitrifying biofilms on small suspended particles in airlift reactors. Biotech. Bioeng. 47 (1995) 585-595

9. Schmidt, J.E.; Molina, J.A.E.; Chiang, C.: Isolation of chemoautotrophic nitrifiers from Maroccan soils. Bull. Ecol. Comm. (Stockholm) 17 (1973) 166-167

10. Sharma, B.; Ahlert, R.: Nitrification and nitrogen removal. Wat. Res. 11 (1977) 897-925

11. Lazarova, V.; Pierzo, V.; Fontvieille, D.; Manem, J.: Integrated approach for biofilm characterization and biomass activity control. Wat. Sci. Tech. 29 (1994) 345-354

12. Clesceri, L.S.; Greenberg, A.E.; Trussel, R.R. Washington: Standard Methods for the Examination of Water and Wastewater, 17th Edition. In: APHA, AWWA, WPCF 1989

13. Kargi, F.; Moo-Young, M.: Transport phenomena in bioprocesses. In: Moo-Young, M.; Blanch, H.W.; Drew. S; Wang, D. I. C. (Eds.): Comprehensive biotechnology, vol. 3, pp. 5-56. Oxford: Pergamon Press 1985

14. Heijnen, J.J.; van Loosdrecht, M.C.M.; Mulder, A.; Tijhuis, L.: Formation of biofilms in a biofilm air-lift suspension reactor. Wat. Sci. Tech. 26 (1992) 647-654

15. Liu, Y.; Capdeville, B.: Dynamics of nitrifying biofilm growth in biological nitrogen removal process. Wat. Sci. Tech. 29 (1994) 377-380

16. van Ginkel, C.G.; Tramper, J.; Luyben, K.Ch. A.M.; Klapwijk A.: Characterization of Nitrosomonas europaea immobilized in calcium alginate. Enzyme Microb. Technol. 5 (1983) 297-303

17. Lazarova, V.; Manem, J.: An innovative process for waste water treatment: the circulating floating bed reactor. Wat. Sci. Tech. 34 (1997) 89-99

18. Rusten, B.; Siljudalen, J.G.; Nordeidet, B.: Upgrading to nitrogen removal with the KMT moving bed biofilm process. Wat. Sci. Tech. 29 (1994) 185-195

19. Karel, S.F.; Libicki, S.B.; Robertson, C.R.: The immobilization of whole cells: Engineering principles. Chemical Engineering Science 40 (1985) 1321-1354 
20 Libicki, S.B.; Salmon, P.M.; Robertson, C.R.: The effective diffusive permeability of a nonreacting solute in microbial cell aggregates. Biotech. Bioeng. 32 (1988) 68-85

21. Fan, L.-S.; Leyva-Ramos, R.; Wisecarver, K.D.; Zehner, B.J.: Diffusion of phenol in a biofilm grown on activated carbon particles in a draft-tube three phase fluidized-bed bioreactor. Biotechnol.Bioeng. 35 (1990) 279-286
22. William, K.; McCarty, P.L.: Verification studies of the biofilm model for bacterial substrate utilization. Journal WPCF 48 (1976) 281-296

23. Onuma, M.; Omura T.: Mass transfer characteristics within microbiol systems. Wat. Sci. Tech. 14 (1982) 553-569

24. Geankoplis, C.J.: Transport processes and unit operations, 3rd Edition. New Jersey: Prentice-Hall, Inc 1993 